\title{
A review of Oligocene and early Miocene European Cricetidae (Mammalia)
}

\section{Matthijs FREUDENTHAL ${ }^{1,2 *}$ \& Elvira MARTÍN-SUÁREZ ${ }^{1}$}

${ }^{1}$ Departamento de Estratigrafía y Paleontología, Universidad de Granada, Avda. Fuentenueva s/n, E-18071 Granada, Spain; mfreuden@ugr.es

${ }^{2}$ Naturalis Biodiversity Center, P.O. Box 9517, NL-2300 RA Leiden, The Netherlands

* Corresponding author

Freudenthal, M. \& Martín-Suárez, E. 2016. A review of Oligocene and early Miocene European Cricetidae (Mammalia) [Revisión de Cricetidae (Mammalia) del Oligoceno y del Mioceno temprano de Europa]. Spanish Journal of Palaeontology, 31 (2), 341-352.

\section{ABSTRACT}

The aim of this paper is to analyze the contents of several genera of European Oligocene and early Miocene Cricetidae, their distinguishing characters, and their stratigraphic distribution. The genera discussed are Atavocricetodon, Eucricetodon, Pseudocricetodon, and Allocricetodon. Several groups are distinguished within the genus Eucricetodon and any of these may constitute a separate (sub)genus. Our results also suggest that Atavocricetodon and Eucricetodon should be retained as separated genera. We restrict our analysis to the European forms because we don't know the Asiatic species.

Keywords: Oligocene, early Miocene, taxonomy, Eucricetodontinae, Pseudocricetodontinae.

\section{RESUMEN}

En este trabajo se analizan varios géneros de cricétidos europeos del Oligoceno y del Mioceno temprano, los caracteres que los diferencian y su distribución estratigráfica. Los géneros tratados son Atavocricetodon, Eucricetodon, Pseudocricetodon, y Allocricetodon. Dentro del género Eucricetodon se han distinguido varios grupos y cada uno de ellos podría formar un (sub)género independiente. Los resultados obtenidos indican que Atavocricetodon y Eucricetodon deberían mantenerse como géneros diferentes. Nuestro análisis se ocupa solo de las formas europeas porque no conocemos las asiáticas.

Palabras clave: Oligoceno, Mioceno temprano, taxonomía, Eucricetodontinae, Pseudocricetodontinae. 


\section{INTRODUCTION}

\subsection{History}

Lartet (1851) created the genus Cricetodon for three species from the Miocene of Sansan (France). Schlosser (1884) included a number of new Oligocene species from Germany. Schaub (1925) again enlarged the number of species and separated the new genera Paracricetodon and Heterocricetodon from Cricetodon. Thaler (1966) created the (sub)genus Eucricetodon for Oligocene and early Miocene cricetids, and distinguished within Eucricetodon a gerandianus-group (containing praecursor, collatus, gerandianus and infralactorensis) and an atavus-group. Later, Thaler (1969) separated Pseudocricetodon from Eucricetodon, including E. incertus (Schlosser, 1884) in the new genus. Mein \& Freudenthal (1971) restricted Eucricetodon to the gerandianus-group of Thaler, and modified its contents; they classified the other species as Eucricetodontinae incertae sedis. Freudenthal (1994) distinguished a group of four late Oligocene species, including E. huerzeleri, E. martinensis, E. margaritae and E. huberi. Freudenthal (1996) suggested that this group might be another genus, different from Eucricetodon, and furthermore created the new genus Atavocricetodon for a number of early Oligocene species. de Bruijn et al. (2003) stated: "The definition of the genus Atavocricetodon has the practical advantage that it unites the primitive small Eucricetodontines into what seems to be a "morpho-subgenus". However, there is no reason to assume that its members are more closely related among them than they are to the more evolved later Eucricetodon species. In other words Atavocricetodon is a grade rather than a clade. We nevertheless maintain Atavocricetodon as a subgenus of Eucricetodon for pragmatical reasons".

Whether one considers it to be a genus or a subgenus has no practical nomenclatorial effects; considering it a grade implies a certain knowledge of its phylogeny, and we think our knowledge in that respect is insufficient.

At present about 40 species of Oligocene and early Miocene cricetids are known from Europe, distributed among the genera Eucricetodon, Atavocricetodon, Pseudocricetodon, Allocricetodon, Paracricetodon, Heterocricetodon, Adelomyarion, and Cincamyarion. Next to those, a dozen species of Eucricetodon and Atavocricetodon, and several other genera (Eocricetodon Wang, 2007, Oxynocricetodon Wang, 2007, and Bagacricetodon Gomes Rodrigues, Marivaux \& VianeyLiaud, 2012) are known from Asia, but here we will only discuss the European contents of the genera Eucricetodon, Atavocricetodon, Allocricetodon, and Pseudocricetodon.

\subsection{Validity of Atavocricetodon}

Gomes Rodrigues et al. (2013) analyzed the shape of the M1 sup. and the enamel structure of the lower incisor of the two genera Atavocricetodon and Eucricetodon, and came to the conclusion that the latter feature does not serve to distinguish taxa. For the analysis of the contour of M1 they used seven species of Eucricetodon and four species of Atavocricetodon, and concluded that Atavocricetodon is a junior synonym of Eucricetodon because their M1 have the same outline. However, they failed to explain why they considered that feature to be more reliable than others, and why they considered it to be decisive for the question of synonymy.

In our opinion, they merely proved that the M1 of these two genera have the same outline, and that does not permit their taxonomic conclusions; their analysis may serve to separate taxa when it detects differences (as it is the case of Pseudocricetodon and Eucricetodon), but similarity of one single feature is no argument.

To test their method they might have included other genera like Eocricetodon Wang, 2007 or Oxynocricetodon Wang, 2007, and especially Bagacricetodon Gomes Rodrigues, Marivaux \& Vianey-Liaud, 2012, a genus created by the same authors almost simultaneously with the paper here under discussion. The M1 of Bagacricetodon (op. cit., fig. 5,19) seems to have the same contour as the Eucricetodon material figured in the same paper and they might have evaluated the validity of Bagacricetodon.

\section{MATERIAL AND METHODS}

We use M1, M2, M3 to designate upper molars, m1, m2, m3 for lower molars. Measurements are given in $0.1 \mathrm{~mm}$ units.

The data are from a large number of publications (Freudenthal, 1996; Hugueney, 1969; Comte, 1985; Daams, 1976; Dienemann, 1987; Vianey-Liaud, 1972, among others), and personal observations on a collection of incisors of Atavocricetodon from Olalla 4A, RGM 558634 - 558639 (Coll. Naturalis, Leiden).

\section{SYSTEMATIC PALAEONTOLOGY}

Family Cricetidae Rochebrune, 1883

Subfamily Eucricetodontinae Mein \& Freudenthal, 1971

Genus Atavocricetodon Freudenthal, 1996.

Freudenthal (1996) gave the following diagnosis of Atavocricetodon: "Eucricetodontinae of very small to 
medium size, with relatively low-crowned cheek teeth, with thin enamel, relatively small cusps, and long crests. Lower molars with or without hypoconid hind arm. $\mathrm{m} 1$ with protoconid hind arm frequently connected to the metaconid. Upper molars generally with a posterior protolophule and an anterior metalophule. M1 generally without a complete anterolophule. Old entoloph on M3 frequently present, or even complete, neo-entoloph fully developed".

To this diagnosis we now add the ornamentation of the lower incisor. In Olalla 4A (Spain), Atavocricetodon is the only cricetid genus, so there can't be any doubt about the identity of the incisors found. Other groups can be discarded, because sciurids are rare and they are larger, eomyids are extremely rare, and glirids have smooth incisors. The anterior face of the incisors (15 specimens studied) from Olalla 4A bears 5 to 7 parallel or slightly diverging fine lines, covering the entire anterior surface, none of them dominating (Fig. 1). In younger localities,
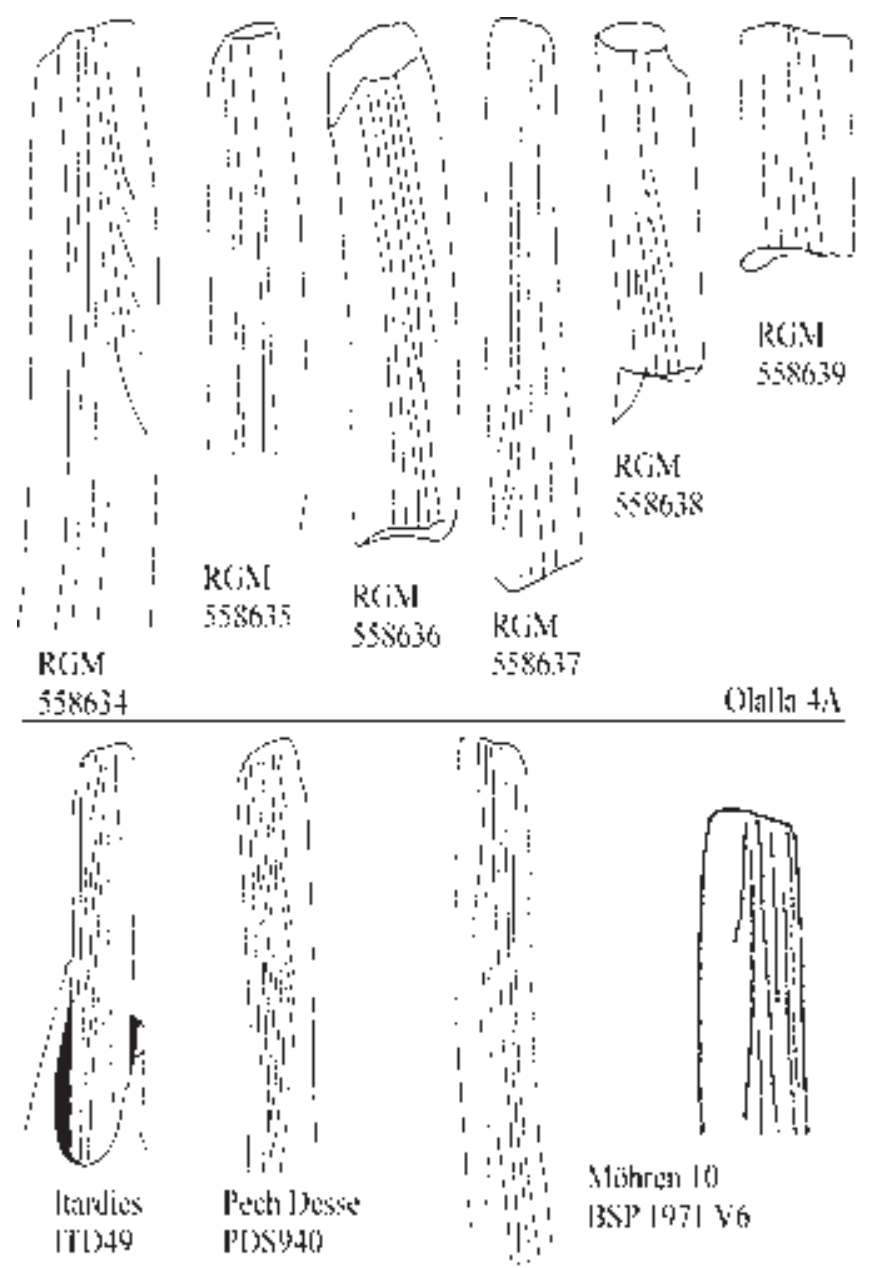

["

Figure 1. Anterior face of the lower incisor of Atavocricetodon from Olalla 4A (RGM 558634 - 558639) and from Itardies, Pech Desse and Möhren 10 (not on scale). like the Montalbán section, Atavocricetodon co-occurs with Pseudocricetodon, and that makes the attribution of the incisors less certain.

The incisor ornamentation is confirmed by Dienemann (1987, fig. 49e), who figured an incisor of A. atavus from Möhren 10 (Germany), nr. BSP 1971 V 6. The latter specimen was also figured by Kalthoff (2000, fig. 42m), who made a somewhat different interpreation (Fig. 1).

Comte (1985, fig. 11a) figured the specimen ITD 49 in mandible of Eucricetodon (= Atavacricetodon) atavus from Itardies (France) with the same parallel or divergent lines as we found in Olalla $4 \mathrm{~A}$, but, according to that author, this specimen also bears two stronger ribs on the external side of the anterior face. In our material, there is a tendency towards a shallow groove separating the first two lines on the external side, and that may have been interpreted by Comte as two stronger ribs.

Maridet et al. (2009) extensively discussed the incisor ornamentation of various Eucricetodon species, both from Europe and Asia. As far as we know, the ornamentation of our Atavacricetodon incisors is not found in any Eucricetodon species: we consider it a reliable character.

Important characters of the molars that distinguish Atavocricetodon from Eucricetodon are the relatively small main cusps, and the long, slender main crests, that connect these cusps. They give the molars a general aspect that is quite different from Eucricetodon (Table 1). For a discussion see below, under Eucricetodon.

Table 1. Differences between Atavocricetodon and Eucricetodon (collatus-group plus huerzeleri-group). Main cusps are protocon(id), metacon(id), hypocon(id), entoconid and paracone; main crests are the connections between the main cusps. Data from personal observation, Freudenthal (1996), Comte (1985), and Dienemann (1987). Several characters are clearly illustrated in Comte (1985, fig. 3). I inf. = inferior incisive.

\begin{tabular}{lll}
\multicolumn{1}{c}{ character } & Atavocricetodon & \multicolumn{1}{c}{ Eucricetodon } \\
\hline main cusps & small & large \\
main crests & long & short \\
enamel & thin & thick \\
valleys & wide & narrow \\
ectolophid & longitudinal & frequently oblique \\
anterocone M1 & simple & simple or split \\
I inf. dominating ribs & no & $2-3$ \\
I inf. fine lines & $5-8$ & sometimes \\
\hline
\end{tabular}

Atavocricetodon comprises six European species, restricted to the early Oligocene (MP21-MP23) (Table 2).

Bahlo (1975) described a small collection of E. atavus from Heimersheim (MP24) and remarked the absence of a protoconid hind arm in $\mathrm{m} 2$ and $\mathrm{m} 3$ and the presence of a cingulum ridge around the protocon(id) that reaches the 
Table 2. Distribution of European Atavocricetodon, Eucricetodon, Pseudocricetodon and Allocricetodon, in a selection of localities. Praec $=$ praecursor Auctorum.

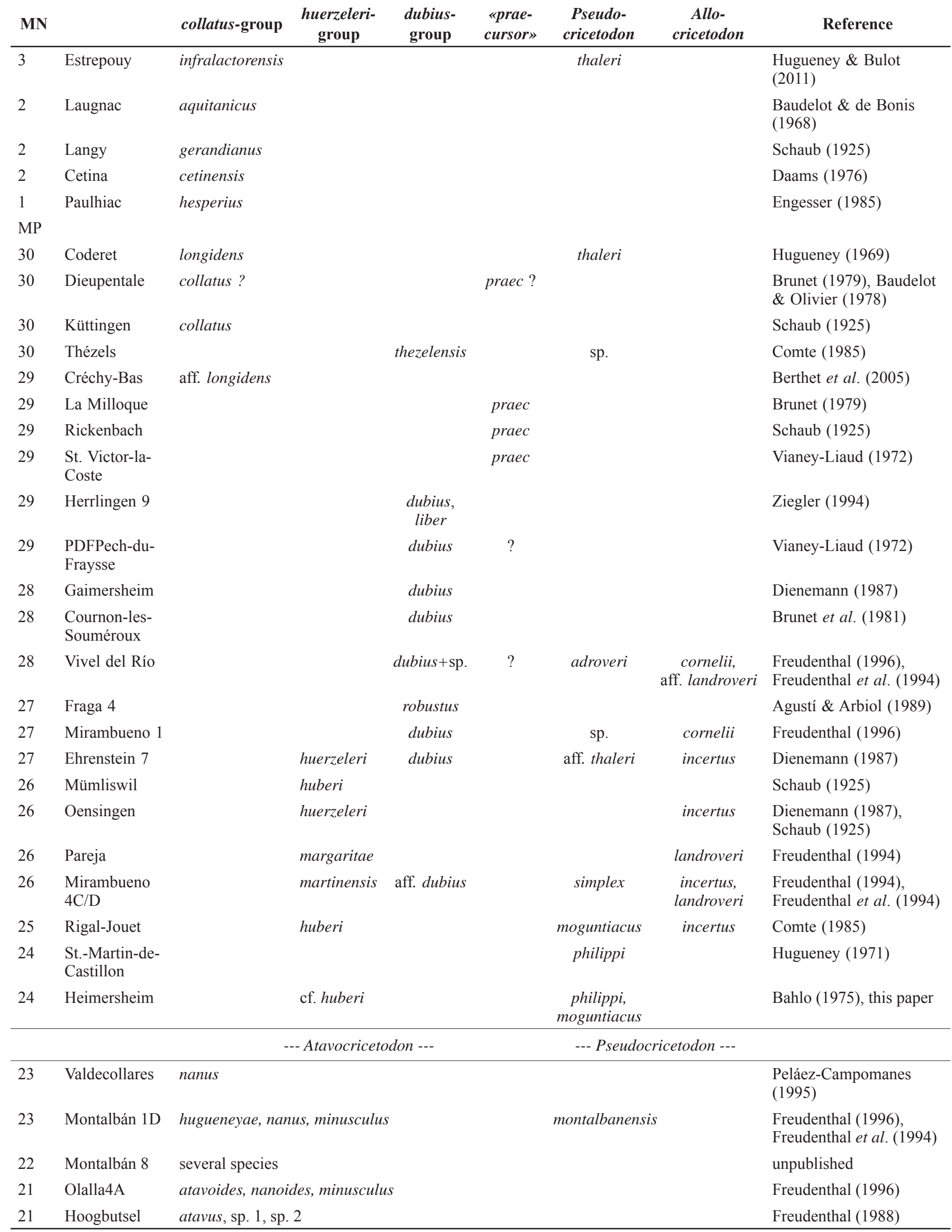


hypocon(id) in $\mathrm{M} 2 / \mathrm{m} 2$. These features are unknown in A. atavus from Hoogbutsel, and extremely rare or absent in any other Atavocricetodon species. The material from Heimersheim is certainly not $A$. atavus, nor does it belong to any other known species of Atavocricetodon. We saw a richer material, kindly lent to us by Prof. Schmidt-Kittler (Mainz), and found the protoconid hind arm of $\mathrm{m} 2$ and $\mathrm{m} 3$ to be absent or very short. This is what Comte (1985) reported for E. huberi. We provisionally classify this material as E. cf. huberi.

Comte (1985) attributed the mandible PDS 940 from the late Oligocene of Pech Desse (MP28, France) to A. cf. atavus, separating it from E. dubius from the same locality, because the lower incisor bears two ribs and many fine lines. The measurements (m1: 18.6 x 11.2; m2: 16.1 x 12.8) are larger than those of any Atavocricetodon known. We don't know where to place this specimen; if it is an Atavocricetodon, it would be the only record of the genus in the late Oligocene.

Dienemann (1987) described the holotype of $E$. murinus (BHM: 1879 XV 170a, München) from Mouillac as having an incisor with 7-8 parallel lines. This probably means that it is an Atavocricetodon or an Allocricetodon, as already suggested by various authors (e.g. de Bruijn et al., 2003; Freudenthal, 1994). The size of its molars (m1: $14.7 \times 9.6 ; \mathrm{m} 2: 13.6 \times 11.5)$ is within the limits of various Atavocricetodon species. In view of the poor material of E. murinus, it is impossible to know which one of these, if any, is a junior synonym. It seems best to avoid the use of the name murinus.

\section{Genus Eucricetodon Thaler, 1966}

Thaler (1966) did not give a diagnosis of this genus. The emended diagnosis given by Dienemann (1987), translated from German, is: "Mostly middle-sized cricetids with bunodont enamel pattern. The predominantly voluminous main cusps are usually not very accentuated and have broad bases. The narrow valleys are constricted by simple, often moderately pronounced ridges".

It must be stressed that this diagnosis includes Atavocricetodon, Eucricetodon incertus, which Thaler (1969) placed in Pseudocricetodon, and which Freudenthal (1994) moved to Allocricetodon, and Eucricetodon dubius, which may well belong to another genus (see below).

Dienemann described material of the species atavus, and on page 21 he stated: "The main cusps are relatively slender, causing the valleys to appear less narrowed" (translated from German). This is exactly what Freudenthal (1996) included in the diagnosis of Atavocricetodon and in contradiction with Dienemann's diagnosis of Eucricetodon. In Table 1 we list the features that serve to distinguish Atavocricetodon and Eucricetodon. Within Eucricetodon we distinguish four groups that may well represent different genera. They are:
Collatus-group. The type-species of Eucricetodon is $E$. collatus (Schaub, 1925), which together with the species $E$. gerandianus (Gervais, 1848-52), E. infralactorensis (Viret, 1930), E. aquitanicus Baudelot \& de Bonis, 1968, E. hesperius Engesser, 1985 and E. longidens Hugueney, 1969 forms a homogeneous group. The general aspect of the molars indicates that E. cetinensis Daams, 1976 belongs to this group too, though the peculiar labial cingulum of $\mathrm{m} 1$ is unknown in other species. The stratigraphic range is MP30-MN2 (Table 2), with one occurrence of E. aff. longidens in MP29 (Créchy-Bas) (Berthet et al., 2005).

The oldest representatives, E. collatus and E. longidens, predominantly have a posterior branch of the hypoconid, a longitudinal ectolophid in $\mathrm{m} 1$ and $\mathrm{m} 2$, and a simple anterocone in M1. In the course of the evolution towards E. infralactorensis the hypoconid hind arm is lost, the ectolophid becomes oblique, and the anterocone is split (Table 3).

Engesser (1985) distinguished the lineage E. collatus - E. hesperius - E. aquitanicus - E. gerandianus - E. infralactorensis, and attributed E. longidens to a separate lineage.

Huerzeleri-group. Freudenthal (1994) characterized E. martinensis Freudenthal, 1994, E. margaritae Daams et al., 1989, E. huberi Schaub, 1925, and E. huerzeleri Vianey-Liaud, 1972 as a fairly homogeneous group with "thick, often crenulated, enamel, and bulky cusps, thick mesoloph(id)s, and frequent presence of a mesoconid or mesocone. In $\mathrm{m} 1$, there is a tendency to enclose a funnel between the protoconid hind-arm, the mesolophid, and the ectolophid; the ectolophid is strongly oblique (anterolabialposterolingual), and the mesolophid is directed forward, perpendicular to the ectolophid". The stratigraphic range is MP25-MP27, with one possible occurrence in MP24 (Table 2).

In this group the hypoconid hind arm is predominantly absent or very short, the ectolophid is oblique, and the anterocone may be split (Table 3). Or, in other words, these species from MP25-MP27 present a derived morphology as compared with E. collatus and E. longidens from MP30. In MP28 and part of MP29, a time span of about 2.5 Ma, no similar species have been recorded and these facts make us conclude that the huerzeleri-group and the collatus-group are not related in an ancestor-descendant relationship. In our opinion, the huerzeleri-group represents a different genus, but for practical reasons, i.e. the similarity with the youngest representatives of the collatus-group, we provisionally keep it in the genus Eucricetodon.

Dubius-group. The cusps are smaller and the crests longer than in the previous groups. The $\mathrm{m} 1$ frequently has an anteroconid connected to the metaconid through a cingulum ridge along the lingual border, and a poorly developed or absent anterolophulid and/or anterior 
Table 3. Comparison of morphological features of the collatus-group and the huerzeleri-group; hedha= hypoconid hind arm. Number of observations between brackets. For references see Table 2 .

\begin{tabular}{|c|c|c|c|c|c|c|c|}
\hline \multirow[b]{2}{*}{ collatus-group } & \multirow[t]{2}{*}{ Locality } & \multirow[t]{2}{*}{ Biozone } & \multicolumn{2}{|c|}{$\begin{array}{c}\text { hedha } \% \\
\text { present }\end{array}$} & \multicolumn{2}{|c|}{ ectolophid oblique } & \multirow{2}{*}{$\begin{array}{c}\begin{array}{c}\text { anterocone } \\
\text { \% split }\end{array} \\
\text { M1 }\end{array}$} \\
\hline & & & $\mathrm{m} 1$ & $\mathrm{~m} 2$ & $\mathrm{~m} 1$ & $\mathrm{~m} 2$ & \\
\hline infralactorensis & Estrepouy & MN3 & $0(91)$ & $0(48)$ & & & yes (67) \\
\hline gerandianus & Saulcet & MN2 & $0(12)$ & $0(19)$ & yes & yes & no (19) \\
\hline gerandianus & Cetina & MN2 & $0(29)$ & $3(30)$ & yes & yes & $50(28)$ \\
\hline cetinensis & Cetina & MN2 & no (1) & (2) & yes & yes & no (1) \\
\hline aquitanicus & Laugnac & MN2 & 0 & 0 & yes/no & yes/no & yes \\
\hline hesperius & Paulhiac & MN1 & $\begin{array}{c}18 \\
(31)\end{array}$ & $\begin{array}{c}10 \\
(29)\end{array}$ & no & no & no (29) \\
\hline longidens & Boudry 2 & MP30 & $\begin{array}{c}63 \\
(33)\end{array}$ & $\begin{array}{c}39 \\
(45)\end{array}$ & no & no & no (32) \\
\hline longidens & Coderet & MP30 & $\begin{array}{c}76 \\
(99)\end{array}$ & $5084)$ & no & no & no (112) \\
\hline collatus & Küttigen & MP30 & $\begin{array}{c}88 \\
(18)\end{array}$ & $\begin{array}{c}38 \\
(23)\end{array}$ & no & no & no (14) \\
\hline \multicolumn{8}{|l|}{ huerzeleri-group } \\
\hline huerzeleri & Ehrenstein 7 & MP27 & $12(8)$ & $0(3)$ & yes & yes & slightly (5) \\
\hline martinensis & Mirambueno 4C/D & MP26 & $\begin{array}{c}14 \\
(21)\end{array}$ & $5(18)$ & yes & yes/no & $25(8)$ \\
\hline margaritae & Pareja & MP26 & $\begin{array}{c}40 \\
(11)\end{array}$ & $\begin{array}{c}10 \\
(10)\end{array}$ & yes & yes/no & $100(6)$ \\
\hline huberi & Rigal-Jouet & MP25 & $\begin{array}{l}\text { rare } \\
(10)\end{array}$ & $\begin{array}{l}\text { rare } \\
(10)\end{array}$ & yes & yes & yes/no (10) \\
\hline cf. huberi & Heimersheim & MP24 & $\begin{array}{c}47 \\
(17)\end{array}$ & $\begin{array}{c}20 \\
(15)\end{array}$ & $11(18)$ & & \\
\hline
\end{tabular}

metalophulid. There may be an ectomesolophid and a double mesolophid and the mesoloph may be placed far backwards.

This group contains E. dubius (Schaub, 1925), E. liber Ziegler, 1994, E. thezelensis Comte, 2000 and an unnamed species that is frequently referred to as E. praecursor. The stratigraphic range is MP27-MP30 with one occurrence in MP26 (Table 2).

E. robustus Agustí \& Arbiol, 1989 from Fraga 4 (MP27) may belong to this group too; in fact, Agustí \& Arbiol (1989) thought it to be derived from E. dubius. In view of the relative lengths of $\mathrm{m} 1, \mathrm{~m} 2$ and $\mathrm{m} 3$ it also might be a Paracricetodon.

Freudenthal (1994) remarked the similarity of the $\mathrm{m} 1$ of E. dubius and Paracricetodon; the latter genus is characterized by its relatively long $\mathrm{m} 3$ and its large size, but de Bruijn et al. (2003) described Paracricetodon wentgesi, of small size, and $\mathrm{m} 1, \mathrm{~m} 2$ and $\mathrm{m} 3$ practically equal in length. Since then the large size and long $\mathrm{m} 3$ are no longer exclusive characters of Paracricetodon and the relation between E. dubius and Paracricetodon needs revision.
Comte (2000; fig. 6m) figured the mandible Th. 6352 of E. thezelensis in which the $\mathrm{m} 3$ is longer than $\mathrm{m} 1$, and in several other mandibles the three molars are almost equal in length. In the specimen Th. 6352, the incisor bears many fine lines, just like Schaub (1925) mentioned for the specimen QT 757, the holotype of Paracricetodon spectabilis (Schlosser, 1884).

In view of these facts, we conclude that (part of) E. dubius and E. thezelensis may well belong to Paracricetodon.

Eucricetodon? dubius (Schaub, 1925)

\section{Synonymy}

1982 Eucricetodon praecursor Lagally

1981 Cricetodon gergovianus (Croizet \& Gervais, non Schaub) Brunet et al.

1981 Cricetodon cournonensis (Lavocat, 1951) Brunet et al.

1981 Eucricetodon quercyi (Vianey-Liaud, 1972) Brunet et al.

1992 Eucricetodon praecursor (Schaub, 1925) Freudenthal et al. 
Holotype. Mandibula sin. with m1-m3, QT764

Type-locality. An unknown fissure in the Quercy (SW France).

Mayo (1982) designated the M2 dext. NMB - Au 1206 as lectotype, but this must be rejected, since Schaub (1925, p. 50) implicitly designated a holotype, when mentioning "die beiden Typusmandibeln" (the two type mandibles) (of dubius and praecursor).

Contrary to the description by Schaub (1925), the incisor of E. dubius bears two ribs, whereas in $E$. praecursor it bears three ribs (personal observation). Schaub (1925) stated that E. praecursor and E. dubius have different length relationships between $\mathrm{m} 1, \mathrm{~m} 2$ and m3, but this is not true either (Freudenthal et al., 1992, fig. 1). The differences in dental morphology of these two specimens, enumerated by the latter authors, might serve to distinguish two species, if they were statistically sustained by a sufficiently large number of specimens, but in this case we have only two specimens of almost the same size and with very similar morphology. In our opinion $E$. praecursor is a synonym of E. dubius, as already said by Freudenthal et al. (1992).

The holotype of E. praecursor is the mandibula dext. with m1-m3, QT763. Vianey-Liaud (1972) designated the M2 UM 1226 from Rickenbach as lectotype, but this is invalid, because Schaub (1925) designated a holotype. The type-locality is an unknown fissure in the Quercy.

Brunet et al. (1981) put Cricetodon gergovianus (Gervais, 1848-52) non Schaub, Cricetodon cournonensis Lavocat, 1951 and Eucricetodon quercyi Vianey-Liaud, 1972 in synonymy with E. dubius.

The oldest record of E. dubius is from Ehrenstein 7 (MP27), the youngest one from Herrlingen 9 (MP29) (Table 2).

On the basis of the shape of the anteroconid of $\mathrm{m} 1$, Freudenthal (1994) hinted at the possibility that the material of E. dubius from Vivel del Río contains two species. One with a blunt shape and hardly indicated anteroconid, the other one more triangular, with a marked anteroconid. The same two morphotypes may be observed in Dienemann (1987, fig. 25).

Most populations of E. dubius are reported to have M1 and M2 with mesolophs that are short or at most of medium length (Table 4), but Freudenthal (1994) said that some M1,2 in Vivel del Río have a long mesoloph. VianeyLiaud (1972) mentioned two M2 out of 18 of E. quercyi (=E. dubius) from Pech-du-Fraysse with long mesoloph. These populations possibly contain a second species, besides E. dubius, which will be discussed hereafter.

\section{Eucricetodon? praecursor Auctorum (non} Schaub, 1925)

\section{Synonymy \\ 1972 Cricetodon praecursor Vianey-Liaud 1979 Cricetodon praecursor Brunet}

As said before, we consider E. praecursor to be a synonym of E. dubius. However, this does not mean that all material attributed to E. praecursor corresponds to E. dubius. The populations from La Milloque and Dieupentale (Brunet, 1979) and St.-Victor-la-Coste (Vianey-Liaud, 1972) frequently have a long mesoloph and represent a different species, which should be given a new name. In fact the latter author considered the long mesoloph as the basis for the species under discussion: "La définition de E. praecursor se base sur un caractère d'ordre statistique, comme pour E. quercyi. E. praecursor diffère de E. collatum par la présence quasi-constante d'un mésolophe atteignant le bord labial de la dent aux molaires supérieures".

It is practically restricted to MP29, with the exception of the population from Dieupentale (Table 2). However, that population was attributed to E. collatus by Baudelot \&

Table 4. Frequency of specimens with long mesoloph in E. dubius. Number of observations between brackets.

\begin{tabular}{|c|c|c|c|c|c|}
\hline MP & locality & species & M1 & M2 & source \\
\hline 29 & Herrlingen 9 & dubius & $?(112)$ & no $(81)$ & Ziegler (1994) \\
\hline 29 & Herrlingen 8 & dubius & $?(101)$ & no $(120)$ & Ziegler (1994) \\
\hline 29 & Pech-du-Fraysse & quercyi & & $2 / 31$ & Vianey-Liaud (1972) \\
\hline 28 & Gaimersheim & dubius & no (123) & no (117) & $\begin{array}{l}\text { Lagally (1982), } \\
\text { Dienemann (1987) }\end{array}$ \\
\hline 28 & Vivel del Río & dubius & yes/no (37) & yes/no (36) & Freudenthal (1994) \\
\hline 27 & Ehrenstein 7 & dubius & no (14) & no (33) & Dienemann (1987) \\
\hline 26 & Mirambueno 4C & aff. dubius & no (5) & no (3) & Freudenthal (1994) \\
\hline
\end{tabular}


Olivier (1978). The bulky cusps of the figured specimens seem to be in favour of the latter interpretation.

It is quite possible that the few specimens of E. dubius with long mesoloph from Vivel del Río and Pech-duFraysse (see under E. dubius) represent E. praecursor Auctorum.

Haslachensis-group. Hugueney (1999) cited the E. hochheimensis - E. haslachensis lineage. Mojon et al. (1985) considered the possibility that this group represents a separate genus.

\section{Eucricetodon ? haslachensis (Schaub, 1925)}

The type-locality, Haslach, is attributed to MN2. Dienemann (1987) attributed a population from Weissenburg 6 (MN1) to E. haslachensis. Apart from its larger size, several details in that description show most similarity with E. praecursor Auctorum.

According to Hugueney (1999), E. haslachensis is characterized by a lophodont and complicated pattern mesoloph(id) often long and double, transverse crests, often constricted or interrupted, and longitudinal crest nearly transverse. Upper first molars with large anterocone and lower molars (m1-m2) generally with long hypoconid hind arm.

\section{Eucricetodon? hochheimensis (Schaub, 1925)}

Only one specimen is known. Engesser (1985) remarked that its dental pattern is very different from other Eucricetodon, and that it might belong to another genus.

Subfamily Pseudocricetodontinae Engesser, 1987

Genus Pseudocricetodon Thaler, 1969

Emended diagnosis. Small Pseudocricetodontinae, foramen incisivum in the maxilla short (posterior border lying before the foremost point of the M1) (Freudenthal et al., 1994).

Lower molars. The ectolophid lies labially of the central axis of the molars. Posterior branch of the hypoconid hardly ever present. $\mathrm{m} 3$ smaller than $\mathrm{m} 1$. Posterior part of $\mathrm{m} 3$ less reduced than in Eucricetodontinae. Protoconid hind-arm in $\mathrm{m} 1$ and $\mathrm{m} 2$ nearly always present, in $\mathrm{m} 1$ nearly always connected to the metaconid. Anterior metalophulid in $\mathrm{m} 1$ frequently absent. In $\mathrm{m} 1$, the metaconid frequently sends a long spur along the border of the molar towards the entoconid. Posterolophid of $\mathrm{m} 1$ hardly curved, running straightly towards the entoconid. In $\mathrm{m} 2$ and $\mathrm{m} 3$, the metalophulid is generally more or less transverse, which, combined with a long anterolophulid, results in a wide anterosinusid.
Upper molars. Mesolophs well developed, often long. Lingual border of M1 straight or concave, or slightly convex, forming an angle of c. $90^{\circ}$ with the posterior border. The prelobe of M1 is frequently set-off from the rest of the molar, the lingual border between anterocone and protocone presenting a sharp angle.

Thaler (1969) described the new genus Pseudocricetodon, and included Cricetodon incertus Schlosser, 1884 in it.

Freudenthal et al. (1994) excluded C. incertus and listed the following Pseudocricetodon species: Pseudocricetodon montalbanensis Thaler, 1969 (type species); P. thaleri (Hugueney, 1969); P. philippi Hugueney, 1971; P. moguntiacus (Bahlo, 1975); Pseudocricetodon sp. nov. (in Freudenthal et al., 1992); P. simplex Freudenthal et al., 1994; P. adroveri Freudenthal et al., 1994. The genus has a very long stratigraphic range, MP23-MN3 (Table 2).

\section{Genus Allocricetodon Freudenthal, 1994}

Diagnosis. (From Freudenthal, 1994). Pseudocricetodontinae of medium size. In $\mathrm{m} 1$, there is a crest descending backwards from the metaconid, along the border of the molar, that may reach the entoconid; in most cases, there is no anterior metalophulid, and the metaconid is connected to the anteroconid along the molar border. In $\mathrm{m} 1$ and $\mathrm{m} 2$, the posterosinusid is completely closed by a high posterolophid. Protoconid hind-arm in $\mathrm{m} 3$ very well developed. In M1, the anterolophule is generally incomplete; instead, there is frequently a longitudinal connection between anterocone and paracone. The posterior wall of the metacone in M1 and M2 is very steep or vertical, sometimes overhanging. The trapezoid shape of M2 is caused by a reduction of both hypocone and metacone.

The type-species of Allocricetodon is A. cornelii Freudenthal, 1994; included species are: A. incertus (Schlosser 1884) and A. landroveri (Daams et al., 1989). The stratigraphic range is MP25-MP28 (Table 2).

Discussion. According to Freudenthal (1994), Allocricetodon is larger than Pseudocricetodon; cingulum ridges closing the valleys of the lower molars are better developed; the metalophulid of $\mathrm{m} 1$ is anterior; and there is a well-developed posterior branch of the protoconid.

Hugueney et al. (1987) placed A. incertus in Adelomyarion and Álvarez Sierra et al. (1999) considered Allocricetodon to be a synonym of Adelomyarion. We don't share that interpretation. In Adelomyarion (MP29-30), the protolophule of M1 is directed forward, which is regarded to be a primitive character, whereas in Allocricetodon (MP25-28) it is directed backwards, which is considered to be derived. Also, the contour of M1 in these two genera is very different. 
De Bruijn et al. (2003) considered the synonymy of Allocricetodon with Pseudocricetodon. That is certainly possible, but a synonymy with Adelomyarion must be rejected.

\section{PHYLOGENY}

Apart from the lineage E. collatus - E. gerandianus $E$ aquitanicus - E. infralactorensis, accepted by several authors (Vianey-Liaud, 1972; Bahlo, 1975; Daams, 1976; Comte, 1985), we find it very difficult to establish ancestordescendent relationships.

In well-documented localities, such as Hoogbutsel, Olalla 4A and Montalbán 1D, Atavocricetodon is represented by three species (Freudenthal, 1996). According to that author, it is not possible to establish evolutionary relationships between these species, due to the mosaic distribution of morphological characters.

Several authors (Comte, 1985; Vianey-Liaud, 1972) supposed an ancestor-descendent relationship between Atavocricetodon and E. huberi. They specifically mentioned A. atavus, but that was the only known species at that time; it could be replaced by one of the species known now. However, there is an abrupt morphological gap between Atavocricetodon and E. huberi, and we think that, at the same time as Allocricetodon (MP25) or somewhat earlier (MP24), E. huberi is an immigrant that gives rise to the huerzeleri-group.

E. dubius and E. praecursor Auctorum are closely related, but not in an ancestor-descendent relationship, because the morphology of E. dubius is more advanced than E. praecursor Auctorum, which is stratigraphically younger.

Comte (1985) supposed E. dubius to be an immigrant, an interpretation we share.

The same author supposed E. collatus to be derived from E. praecursor and E. longidens from E. dubius without giving clear justifications. In our opinion there are no arguments for that hypothesis, and we interpret the collatus-group as an immigrant. We don't think it is derived from the huerzeleri-group, because its oldest representatives present plesiomorphic characters that have already disappeared in the huerzeleri-group.

Although it is generally assumed that European Eucricetodontinae are immigrants, derived from Asiatic predecessors, it is not possible to create concrete links between species. Gomes Rodrigues et al. (2012) stated that early Oligocene Chinese cricetids already show retroverse lophs in the upper molars, whereas European forms do not show this - supposedly modern - feature before the Miocene.

\section{CONCLUSIONS}

Eight genera of Cricetidae are present in the European Oligocene: Eucricetodon, Atavocricetodon, Pseudocricetodon, Allocricetodon, Paracricetodon, Heterocricetodon, Adelomyarion, and Cincamyarion.

We reject the synonymy of Atavocricetodon with Eucricetodon proposed by Gomes Rodrigues et al. (2013). Atavocricetodon is restricted to the early Oligocene and Eucricetodon is composed of several groups (collatus, huerzeleri, dubius and haslachensis), which may well be different genera, and which immigrate at different times during the late Oligocene.

We also reject the synonymy of Allocricetodon and Adelomyarion, supposed by various authors.

\section{ACKNOWLEDGMENTS}

Thanks are due to Dr F. Ruiz (Valencia) and an anonymous reviewer who helped to improve this paper. This study was supported by the research group RNM190 of the Junta de Andalucía.

\section{REFERENCES}

Agustí, J. \& Arbiol, S. 1989. Nouvelles espèces de rongeurs (Mammalia) dans l'Oligocène supérieur du Bassin de l'Ebre (N.E. de l'Espagne). Géobios, 22, 265-275.

Álvarez Sierra, M.A., Daams, R. \& Peláez-Campomanes, P. 1999. The Late Oligocene rodent faunas of Canales (MP28) and Parrales (MP29) from the Loranca Basin, province of Cuenca, Spain. Revista Española Paleontología, 14, 93-116.

Bahlo, E. 1975. Die Nagetierfauna von Heimersheim bei Alzey (Rheinhessen, Westdeutschland) aus dem Grenzbereich Mittel/Oberoligozän und ihre stratigrafische Stellung. Abhandlungen Hessisches Landesamt für Bodenforschung, 71, 1-182.

Baudelot, S. \& de Bonis, L. 1968. Contribution à l'étude des Rongeurs de l'Aquitanien moyen et supérieur de l'Agenais. Bulletin Société Histoire Naturelle Toulouse, 104, 160-164.

Baudelot, S. \& Olivier, P. 1978. Les rongeurs (Mammalia, Rodentia) de l'Oligocène terminal de Dieupentale (SudOuest de la France: Tarn-et-Garonne). Géobios, 11, 5-19.

Berthet, D., Escuillé, F. \& Hugueney, M. 2005. Les faunes de petits mammifères de Billy-Crechy (Allier) à la transition Oligocène-Miocène. Cahiers scientifiques Museum Lyon, $8,7-32$.

Brunet, M. 1979. Les Cricetidae (Rodentia, Mammalia) de la Milloque (bassin d'Aquitaine): horizon repère de l’Oligocène supérieur. Géobios, 12, 653-673. 
Brunet, M., Hugueney, M. \& Jehenne, Y. 1981. Cournon-lesSouméroux: un nouveau site à vertébrés d'Auvergne; sa place parmi les faunes de l'Oligocène supérieur d'Europe. Géobios, 14, 323-359.

Comte, B. 1985. Éléments nouveaux sur l'évolution des genres Eucricetodon et Pseudocricetodon (Eucricetodontinae, Rodentia, Mammalia) de l'Oligocène d'Europe occidentale. Palaeovertebrata, 15, 1-69.

Comte, B. 2000. Rythme et modalités de l'évolution chez les ronguers à la fin de l'Oligocène. Leurs relations avec les changements de l'environnement. Palaeovertebrata, 29, 83-360.

Daams, R. 1976. Miocene Rodents (Mammalia) from Cetina de Aragón (Prov. Zaragoza) and Buñol (Prov. Valencia), Spain. Proceedings Koninklijke Nederlandse Akademie van Wetenschappen, B, 79, 3, 152-182.

Daams, R., Freudenthal, M., Lacomba, J.I. \& Álvarez, M.A. 1989. Upper Oligocene micromammals from Pareja, Loranca Basin, prov. of Guadalajara, Spain. Scripta Geologica, 89, 27-56.

De Bruijn, H., Ünay, E., Saraç, G. \& Yilmaz, A. 2003. A rodent assemblage from the Eo/Oligocene boundary interval near Süngülü, Lesser Caucasus, Turkey. Coloquios de Paleontología, Volumen Extraordinario, 1, 47-76.

Dienemann, A. 1987. Die Gattungen Eucricetodon und Pseudocricetodon (Rodentia, Mammalia) aus dem Oligozän Süddeutschlands. Abhandlungen Bayerische Akademie Wissenschaften, mathematisch-naturwissenschaftliche Klasse, N.F., 165, 1-158.

Engesser, B. 1985. Die Gattung Eucricetodon (Mammalia, Rodentia) im Grenzbereich Oligozän/Miozän. Eclogae Geologicae Helvetiae, 78, 669-692.

Freudenthal, M. 1988. Redescription of Eucricetodon atavus (Misonne, 1957) from Hoogbutsel (Belgium). Bulletin Institut Royal Sciences Naturelles Belgique, Sciences de la Terre, 58, 199-207.

Freudenthal, M. 1994. Cricetidae (Rodentia, Mammalia) from the Upper Oligocene of Mirambueno and Vivel del Río (Teruel, Spain). Scripta Geologica, 104, 1-55.

Freudenthal, M. 1996. The Early Oligocene rodent fauna of Olalla 4A (Teruel, Spain). Scripta Geologica, 112, 1-67.

Freudenthal, M., Hugueney, M. \& Moissenet, E. 1994. The genus Pseudocricetodon (Cricetidae, Mammalia) in the Upper Oligocene of the province of Teruel (Spain). Scripta Geologica, 104, 57-114.

Freudenthal, M., Lacomba, J.I. \& Sacristán, A. 1992. Classification of European Oligocene cricetids. Revista Española de Paleontología, no. Extra, 49-57.

Gervais, P. 1848-52. Zoologie et Paléontologie Françaises (Animaux Vertébrés) ou Nouvelles Recherches sur les Animaux Vivants et Fossiles de la France (Tome II). Arthus Bertrand, Paris.

Gomes Rodrigues, H., Marivaux, L. \& Vianey-Liaud, M. 2012. The Cricetidae (Rodentia, Mammalia) from the Ulantatal area (Inner Mongolia, China): new data concerning the evolution of Asian cricetids during Oligocene. Journal of Asian Earth Sciences, 56, 160-179; doi: 10.1016/j.jseaes.2012.05.007.
Gomes Rodrigues, H., Marivaux, L. \& Vianey-Liaud, M. 2013. On the status of early Eucricetodontinae (Muroidea, Rodentia) with a special focus on the Atavocricetodon vs. Eucricetodon issue: morphometrical and microstructural aspects. Spanish Journal of Palaeontology, 28, 17-28.

Hugueney, M. 1969. Les rongeurs (Mammalia) de l'Oligocène supérieur de Coderet-Bransat (Allier). Documents Laboratoire Géologie Faculté des Sciences Lyon, 34, 1-227.

Hugueney, M. 1971. Pseudocricetodon philippi, nouvelle espèce de Cricétidé (Rodentia, Mammalia) de l'Oligocène moyen de Saint-Martin-de-Castillon (Vaucluse). Comptes rendus Académie des Sciences Paris, D, 272, 2533-2535.

Hugueney, M. 1999. Genera Eucricetodon and Pseudocricetodon. In: The Miocene Land Mammals of Europe (eds Rössner, G.E. \& Heissig, K.). Verlag F. Pfeil, München, 347-358.

Hugueney, M. \& Bulot, C. 2011. Les petits Mammifères du Burdigalien (MN3; Miocène) d'Estrepouy (Gers, France): liste faunique actualisée. Estudios Geológicos, 67, 427442; doi: 10.3989/egeol.40584.200.

Hugueney, M., Adrover, R., Moissenet, E. \& SchmidtKittler, N. 1987. Les Mammifères de Vivel del Río (prov. de Teruel, Espagne; Oligocène supérieur): un riche gisement stratifié en comparaison avec des faunes karstiques. In: International Sympium on Mammal. Biostratigraphy and Paleoecology of the European Paleogene, Mainz, Febr. 18-21 (ed. Schmidt-Kittler, N.). Münchner Geowissenschaftliche Abhandlungen, A, 10, 117-130.

Kalthoff, D. 2000. Die Schmelzmikrostruktur in den Incisiven der hamsterartigen Nagetiere und anderer Myomorpha (Rodentia, Mammalia). Palaeontographica, A, 259, 1-193.

Lagally, A. 1982. Morphologisch-biostatistische Untersuchungen an Eucricetodon (Mammalia, Rodentia) der oligozänen Säugetierlagerstätten Möhren 13 und Gaimersheim (Fränkischer Jura). Zitteliana, 9, 3-36.

Lartet, E. 1851. Notice sur la Colline de Sansan. 1-47. Portes, Auch.

Lavocat, R. 1951. Révision de la faune des mammifères oligocènes d'Auvergne et du Velay. Sciences et Avenir, 1951, 1-153.

Maridet, O., Wu, W., Ye, J., Bi, S., Ni, X. \& Meng, J. 2009. Eucricetodon (Rodentia, Mammalia) from the Late Oligocene of the Junggar basin, northern Xinjiang, China. American Museum Novitates, 3665, 1-21; doi: 10.1206/676.1.

Mayo, N.A. 1982. Bemerkungen zur Systematik und Evolution einiger Theridomyidae und Cricetidae (Rodentia, Mammalia) des Oligozäns: Antwort an M. Vianey-Liaud. Eclogae Geologicae Helvetiae, 75, 697-719.

Mein, P. \& Freudenthal, M. 1971. Une nouvelle classification des Cricetidae (Mammalia, Rodentia) du Tertiaire de l'Europe. Scripta Geologica, 2, 1-37.

Mojon, P.O., Engesser, B., Berger, J.P., Bucher, H. \& Weidmann, M. 1985. Sur l'âge de la Molasse d'Eau douce inférieure de Boudry NE. Eclogae Geologicae Helvetiae, $78,631-667$. 
Peláez-Campomanes, P. 1995. Valdecollares: a rodent fauna from the lower Oligocene of the Loranca Basin (Cuenca, Spain). Proceedings Koninklijke Nederlandse Akademie van Wetenschappen, 98, 265-289.

Rochebrune, A.T. 1883. Faune de la Sénégambie. Mammifères. Actes de la Société Linnéenne de Bordeaux, 37, 49-203.

Schaub, S. 1925. Die hamsterartigen Nagetiere des Tertiärs und ihre lebenden Verwandten. Abhandlungen der Schweizerischen Paläontologischen Gesellschaft, 45, 1-114.

Schlosser, M. 1884. Die Nager des Europäischen Tertiärs. Palaeontographica, 31, 19-162.

Thaler, L. 1966. Les rongeurs fossiles du Bas-Languedoc dans leurs rapports avec l'histoire des faunes et la stratigraphie du Tertiaire d'Europe. Mémoires Museum National Histoire Naturelle, C, 17, 1-295.
Thaler, L. 1969. Rongeurs nouveaux de l'Oligocène moyen d'Espagne. Palaeovertebrata, 2, 191-207.

Vianey-Liaud, M. 1972. Contribution à l'étude des Cricétidés oligocènes d'Europe occidentale. Palaeovertebrata, $5,1-44$.

Viret, J. 1930. In: Roman \& Viret. Le Miocène continental de l'Armagnac et le gisement burdigalien de La Romieu (Gers). Société Géologique de France, Livre Jubilaire, 2, 577-604.

Wang, B. 2007. Late Eocene cricetids (Rodentia, Mammalia) from Nei Mongol, China. Vertebrata Palasiatica, 45, 195-212.

Ziegler, R. 1994. Rodentia (Mammalia) aus den oberoligozänen Spaltenfüllungen Herrlingen 8 und Herrlingen 9 bei Ulm (Baden-Württemberg). Stuttgarter Beiträge Naturkunde, B, 196, 1-81. 
